\title{
Anticipating Democracy
}

\section{“Confucian Democracy": Dead Ends and Alternatives}

The notion of a Confucian democracy receives considerable attention in the academic world today, but unfortunately Confucianism is often identified summarily and uncritically as the historical essence of China, or even of East Asia more generally. Imagining that Confucianism could be a cultural remedy for the defective political reality of democracy still influences the political thought of many proponents of Confucianism. So far, no "Confucian democracy" has existed in any country, and none of the political ideas associated with it has had a profound impact on international discussions of democracy theory, let alone an impact on the institutions of existing democracies. The only noteworthy exception, if one wants to consider it Confucian, is Sun Yat-sen's model of five constitutional powers, as it survives on the island of Taiwan.

Many recent studies of Confucian democracy are located in the field of Chinese Studies, where political philosophy and various social sciences intersect. These studies focus on (traditional) Confucian themes regarded as relevant to theories of democracy in the broadest sense, including concepts of political participation, human rights, and citizenship. When they elaborate on how to inscribe elements of Confucian thought into Western democratic thought (such as pragmatism or communitarianism), it is usually in reference to the "classical" pre-Qin periods of Confucian thought. At most, concepts of democracy as developed by modern Confucians such as Tang Junyi and Mou Zongsan are considered in passing. ${ }^{1}$

Chinese thinkers have debated "democracy and Confucianism" since the early 2oth century, though often in quite inconsistent and contradictory ways. Given Confucianism's dubious record when it comes to promoting democracy in China, this is hardly surprising. Early in the Republican period, positions ranged from identifying Confucianism as the ideological enemy of political

1 Recent titles include Tan, Confucian Democracy; He, "Rujia zhengzhi zhexue de qianjing;" Jang, "A Confucian Deliberation on Rawls's Liberal Conception of International Justice;" Jin, Zhongguo min ben sixiang shi; and Hall, Democracy of the Dead. Bell's Confucianism for the Modern World takes a different path in attempting to identify Confucian political or religious institutions and relate them to democratic ideas and institutions.

(C) THOMAS FRÖHLICH, 2017 | DOI 10.1163/9789004330139_010 
democracy (and of republicanism) ${ }^{2}$ to portraying it as a repository of traditional Chinese ideas and institutions conducive to solidifying, if not improving on, Western models of constitutional democracy in a Chinese context. Zhang Junmai, for example, accentuated how conducive the Confucian tradition is to developing civic virtues, which he understood as a necessary pre-condition of nation-building and, consequently, democracy. ${ }^{3}$ In a quite different vein, claims to improve Western democracy through the Confucian tradition are abundant in right-wing GMD ideology (such as in the New Life Movement of the 1930s) and also can be found in Sun Yat-sen's thought. ${ }^{4}$ The major parameters for discussing the compatibility of Confucianism with democracy thus were set decades before the contemporary debate about so-called Asian values began.

Although Mainland Chinese intellectuals who favor "Confucian democracy" often critique China's present government and its policies (mostly within the limits sanctioned by the CCP), some are equally critical of Western democracies. Jiang Qing, for example, strongly emphasizes the (seemingly foreseeable) superiority of a Confucian(ized) democracy over "Western liberal democracies." Similar tendencies can be found when the CCP highly praises China's democratic tradition, which is seen as embodied in pre-modern Chinese notions of a common welfare and rests on the idea of a government adhering to the principles of the "people as foundation" (min ben 民本). ${ }^{6}$ Much in the same vein, Chinese "neo-conservatives" of the 1990s stressed the necessity of establishing Confucian nationalism as a foundation for a future Chinese democracy. ${ }^{7}$

The conceptualization of Confucianism varies widely in these contexts, but two features clearly stand out. First, Confucianism is understood in relation to

2 For example, Chen, “Xin Qingnian zui'an zhi dabianshu," pp. 361-362.

3 Zhang, "Xueshujie zhi fangxiang yu xuezhe zhi zeren" pp. 203, 224.

4 On the political implications of the GMD regime's official "Confucianism" between 1949 and 1987, see Zhongguo wenhua xiehui (ed.). Zhonghua wenhua fuxing yundong, pp. 5-7; Chun, "From Nationalism to Nationalizing," pp. 138-141.

5 See Jiang, Zhengzhi ruxue.

6 Wen, "Wen Jiabao zongli lun Huang Zongxi sixiang de qin bi xin," p. 5. It is ironic that it was a staunch anti-communist thinker like Xu Fuguan who highlighted the idea of "people as foundation" in a similar manner. In an article from 1951, which he published in exile, Xu interpreted this idea as an equivalent of the "principle of rule by virtue" (dezhizhuyi 德治主義), calling it the "highest maxim" of Confucian political thought; see Xu, "Rujia zhengzhi sixiang de gouzao ji qi zhuanjin," p. 49.

7 Xiao, Yu zhengzhi langmanzhuyi gaobie, p. 229. 
modernization. China's position in the modern world here is seen optimistically, and the proponents view Confucianism as one of China's crucial assets. They think it holds the promise of being able to create a successful modern state (including democratic government), if not of being superior to political modernity as experienced in the West. Second, there are strong tendencies to define Confucianism as a cluster of values - whether political, social, cultural, or religious. Confucianism might even be portrayed as a Chinese or East Asian mentality that plays an important role in the value orientation of all individuals. ${ }^{8}$ Confucian values and virtues are often linked to notions of individual self-cultivation, or the self-transformation of entire communities. From this perspective, the quality of democratic government seems to depend to a large extent on the "cultivation" of personal qualities and virtues by either rulers or citizens, or on the kind of values they share and put into practice. ${ }^{9}$ The Great Learning is often cited in this context with the traditionalistic assumption that standards of personal self-cultivation are the yardstick for the quality of modern democracies. ${ }^{10}$

It should be noted here that the notion that individual or collective self-cultivation is embedded in certain clusters of values is distinctly modern. The very idea of values, and therefore that of a community united in common values that an individual wasfree to accept or reject, was asforeign to pre-2oth centuryChina as it was to pre-19th century European thought (apart from the "values" implied in 18th century economic thought $\left.{ }^{11}\right)$. The increased currency of "values," a term

8 In related international debates on Asian values, one end of the spectrum is represented by Francis Fukuyama's conflation of Confucianism and democracy, the other end by Samuel Huntington's declaration that they stand in inherent contradiction; see Fukuyama, "Confucianism and Democracy"; Huntington, "Democracy's Third Wave," pp. 15, 18, 21. Neither Fukuyama nor Huntington are specialists in Chinese studies, yet similar value-based conceptions of Confucianism, Confucian self-cultivation or Confucian communities can also be found in more specialized studies.

9 From the vantage point of such conceptions of Confucianism, Western democracies are accordingly understood in terms of values and normative principles, and less in terms of institutions and procedures.

10 Anne Cheng calls the contemporary tendency to ignore the historical horizon of The Great Learning in interpreting "self-cultivation" "jack-of-all-trades Confucianism:" Cheng, "The Way of Confucius and sprouts of democracy," pp. 20, 24; see also Cheng, "Des germs de démocratie dans la tradition confucéene?," pp. 102-104. For an analysis of the reception of The Great Learning in Chinese political thought of the 2oth century, see Fröhlich, "Regulating, Governing, and Pacifying the Modern World: Optimism Regarding Progress in Chinese Interpretations of the Great Learning."

11 Joas, Die Entstehung der Werte, p. 37. 
rendered in modern Chinese by the neologism jiazhi 價值, in Chinese discussions about Confucianism could plausibly be related to the breakdown of the imperial cult of state at the beginning of the 2oth century and the prolonged failure of the republican state after 1912. There has thus been a tendency since the 1910 s to overemphasize, in an almost cultish manner, the notions of values and a value-centered culture. This should probably be regarded, as mentioned before, as compensatory — as a quasi-religious veneration of "values" and "culture" intended to replace the sacral significance of the former imperial cult.

Obviously, the discourses about Confucian values and the identifications of "Chinese culture" with Confucianism are intertwined with considerations about cultural particularity and universality in theories of modernity and modernization. With respect to the issue of "Confucianism and democracy," two positions are particularly relevant:

(1) Support of Confucianism's potential to embellish or even overcome liberal democracy, based on particularistic assumptions of modernization. The cultural uniqueness of China's political modernity is highlighted here and democracy is only accepted in a specifically Chinese variant, so that institutional adjustments need to be made to Sinicize democracy. Sun Yat-sen's constitutional blueprint, for example, adds the governmental powers of the control yuan and examination yuan to the executive, legislative, and judicial powers. Likewise, in his lectures on "people's rights" (min quan 民權) in The Three Principles of the People, he suggested a "Chinese solution" for what he deemed to be the fundamental problem of Western democracies: the lack of trust between government and citizens. Sun's "solution" is linked to what he identified as the Chinese tradition of meritocratic thought and institutions, meaning the governance of elites composed of capable, virtuous men.

Still, despite Sun's emphasis on the Chinese tradition, it is likely he drew upon European liberal thought, and J.S. Mill in particular, that argued for independent political representation by elites, whom he deemed capable of making wiser judgments than the mass of less educated citizens (see, for example, Mill's Considerations on Representative Government from 1861). Broad political participation and popular sovereignty would thus be restrained. This pertains also to the position of Singapore's Lee Kuan Yew who, in 1992, recommended that the voting laws be changed to award a double vote to those in their 4os and 5 os to reflect their broader experience in taking responsibility for their families and hence their superiority in making reasonable decisions. ${ }^{12}$ Jiang Qing's "political Confucianism" and his idea of adding a Chamber of Confucians to a parliamentary representation system can be included here. Jiang views

Heinz, “Vom Mythos der 'Asiatischen Werte," pp. 6o-61. 
"democratic ideas" such as freedom, equality, the rule of law, and human rights as typically Western and favors a more "substantial" Confucian type of political democracy instead that would guarantee the moral quality of voters and politicians alike. ${ }^{13}$ Such approaches entail strong elitist, if not authoritarian tendencies. Yet, as we have seen in the case of Sun Yat-sen, the allegedly typical Confucian or Chinese enhancement of democracy may in fact have roots in the Chinese reception of Western political thought. It seems that the elitist strands of European liberalism of the 18th and 19th century which often resulted from a need to defend social and political privilege were adopted by Chinese thinkers who attempted to establish a strong, modern nation-state.

(2) The second position is closely related to modernization theory and its assertion that, in the long run, there will be a world-wide convergence of modernization. From this perspective, considerations about "Confucianism and democracy" do not center on the question of how Confucianism can enhance (Western) democracy, but rather on whether Confucianism is compatible with political modernization, i.e. democracy. Early examples of this approach can be found, for example, in the work of Hu Shi or Chen Duxiu. Both of these major thinkers of the New Culture Movement have asked why China has failed, so far, to develop a democracy on its own. Their answers point to the conclusion that there is an incompatibility between Confucianism and democracy. Contemporary Confucianism outside the Chinese Mainland, such as in Taiwan or the United States, generally assumes instead that the two are compatible. Tu Wei-ming's theory of multiple modernities, for example, emphasizes that there are culturally specific versions of modernity (hence the plural "modernities"), but it still presumes a universal convergence of clusters of core values, ideas and practices. This convergence contains, among others, concepts of democracy, open society, and scientific progress that originated in the West. ${ }^{14}$ According to $\mathrm{Tu}$, concepts of individual rights, constitutionalism, natural law, and individual freedom were indeed absent in Confucianism, but they can now be integrated into a globally evolving Confucian discourse on democ-

13 Jiang, Zhengzhi ruxue, pp. 22-23, 283-284, 366-368. Jiang elaborates his idea of a "chamber of Confucians" only in the Taiwanese edition of his book; see Sébastien Billioud's translation: Jiang, "Le confucianisme de la 'Voie royale', direction pour le politique en Chine contemporaine," p. 117. For an English translation of texts by Jiang Qing on the enlarged, tricameral legislature and on the political key function of a Confucian academy, see Jiang, A Confucian Constitutional Order: How China's Ancient Past Can Shape Its Political Future, Chap. 1 and 2. David Elstein has discussed Jiang's proposal of a tricameral legislature from the perspective of the question of political legitimacy: Elstein, Democracy in Contemporary Confucian Philosophy, pp. 146-147. 
racy, without however contorting Confucianism itself. Against this backdrop, Tu argues that, in fact "Confucian personality ideals" would be "realized more fully" in a liberal democracy. ${ }^{15}$

In the 1950s and 196os, Tang Junyi, Xu Fuguan, and Mou Zongsan also discussed the relationship between Confucianism and democracy. Whereas Xu Fuguan is often portrayed as the most practical-minded political thinker of the three, Tang and Mou are commonly recognized as eminent proponents of Confucian ethics and metaphysics. Unfortunately, their ideas of democracy in particular, and political philosophy in general, receive little attention, even among contemporary Confucians. This is regrettable because their notion of a Chinese democracy in the making transcends many of the culturalist boundaries that limit the discourse on Confucian democracy. To begin with, Tang Junyi and Mou Zongsan were both convinced that the political tradition of Confucianism cannot function as a normative resource of liberal democracy, but ought to be seen instead as harmful to it. Mou Zongsan singled out a meritocratic form of "administrative democracy" that was void of any trace of constitutional government but was prevalent in pre-modern China. In Mou's view, this kind of administrative democracy must not be confused with political democracy. Political democracy was unknown in pre-modern China, and if the two notions were conflated, he suggested, efforts to introduce liberal democracy to modern China were doomed to fail. ${ }^{16}$

Tang also set out to find the limitations in the political tradition of Confucianism and to use this critique as a resource for his discussion of liberal democracy. ${ }^{17} \mathrm{He}$ criticized the concept of political action held by the pre-modern Confucians as reductionist and dangerous, exactly because they had understood political action in terms of a person's moral awareness and ethical standards. He assumed that, if they were to live in modern times, his Confucian predecessors would have falsely concluded that the struggle of

15 Ibid., pp. 70-71.

16 On Mou Zongsan's theory of democracy and his analysis of pre-modern Confucian political thought, see my "'Confucian Democracy' and its Confucian Critics: Mou Zongsan and Tang Junyi on the Limits of Confucianism," pp. 177-183. Peng Guoxiang's book-length study on Mou's political thought also addresses these issues. Due to its date of publication, I could not include it in my study; see Peng, Zhizhe de xianshi guanhuai: Mou Zongsan de zhengzhiyu shehui sixiang.

17 Tang applied a broad concept of democracy comprising constitutional government, the rule of law, general elections, parliamentary representation, and a multi-party system. Yet he neither discussed specific aspects of constitutional law, the scope of participation in a representative democracy, nor the difference of presidential and cabinet systems of government. 
individuals to protect their rights only amounted to morally questionable, selfish behavior. The Confucians would have failed to understand that the struggle for one's rights heightened the need for checks and balances among contesting wills for power, and hence produced something politically desirable. ${ }^{18}$ This affirmation of an individual struggle for rights clearly goes against the grain of Confucian traditions. Tang was not the only modern Confucian thinker to point out that no conception of the individual's struggle for political rights had ever emerged in the Confucian tradition. In 1951, Xu Fuguan had already come to the same conclusion when pondering why Confucianism had at best managed to mitigate harsh autocratic rule in pre-modern China, but failed to lay a foundation for democratic constitutional rule. In this context, Xu had identified as a historical root of modern Western democracy the individual's struggle for political rights, which he believed had been absent from China not least because of the Confucian idea of "rule by virtue" (dezhi 德治). ${ }^{19}$

According to Tang, pre-modern Confucians were content with conceptualizing political acts in general, and power relations such as the one between emperor and prime minister in particular, as belonging to the ethical perspective of the so-called five cardinal relationships (wu lun 五倫). ${ }^{20}$ Tang assumed, in other words, that these Confucians were still convinced that educational, ethical, and religious means would suffice to normatively shape political power. They thus neglected the importance of constitutional law and institutional measures offering checks and balances. As a case in point, Tang cited the Confucians of the Han Dynasty. He held them responsible for the belief that practical politics might be contained by a "religious mind," as evidenced by their attempts to convince the emperor to worship Confucius as a deity. As regards Confucians of the Song and Ming Dynasties they are said to have aimed for the independence of scholarship from politics, and the formation of politics by means of education, lectures, and writings, and by establishing academies and scholarly associations. Tang provided yet another example, referring to measures to check political power implemented in the context of local self-administration, such as the ancient model of the so-called wellfield system or, in the Song Dynasty, the so-called community compacts. He concluded that these were both unsuccessful attempts to contain "real politi-

18 Tang, Wenhua yishi yu daode lixing, pp. 290-291.

$19 \mathrm{Xu}$, "Rujia zhengzhi sixiang de gouzao ji qi zhuanjin," pp. 49-50, 53-54; on Xu see also Huang, Dongya ruxue shiyu zhong de Xu Fuguan ji qi sixiang, pp. 223-224.

20 The other relations are those of father and son, husband and wife, older and younger brother, and of friends. 
cal power" in the spirit of "social humanism."21 Still, Tang was not fundamentally opposed to the idea that politics as well as the ethical "transformation [of human beings] through [Confucian] teachings" should both assist human beings in actualizing their potential for self-fulfillment as endowed to them by Heaven. ${ }^{22}$

In abandoning the political tradition of Confucianism and its notions of benevolent rule by superior individuals, Tang and Mou Zongsan conceptualized political power in a way that they claimed was never done in China's traditional political philosophies. A salient feature of their brand of modern Confucianism is the view that justifications of liberal democracy need to take into account that politics necessarily operates according to the logic of political power and, therefore, should not be envisioned as an appendix to ethics. Tang and Mou placed this justification within a distinct historical outlook in order to assert that liberal democracy is Confucianism's authentic political form, and hence that Confucianism can only fulfill itself in modern society. ${ }^{23}$ According to Mou Zongsan, "Confucian rationalism" (rujia de lixingzhuyi 儒家的理性主義) had never been comprehensively manifested in pre-modern Chinese politics. Mou asserted that it can only achieve this now due to the introduction of a "renewed outer king" (xin wai wang 新外王), by which he meant democracy and science. ${ }^{24} \mathrm{Xu}$ Fuguan shared with Tang Junyi and Mou Zongsan the view that the modern reconstruction of Confucianism ultimately pointed toward a constitutional democracy as its political form. However, whereas Tang and Mou focused on the justification of constitutional democracy in terms of Confucianism, $\mathrm{Xu}$ seems to have been considerably more ambitious. He further anticipated a future Confucian democracy characterized by a renewed infusion of Confucian ethics into democratic politics. This would lead, as Xu expected, to a substitution of the individual's struggle for rights

21 Tang, Renwen jingshen zhi chongjian, p. 422.

22 Ibid., p. 417. He indeed saw "transformation through teachings" as emphasizing the selfdetermination of the individual. See also Mou, Zheng dao yu zhi dao, pp. 124-125. Tang accordingly emphasized the aspect of individual self-fulfillment within the speculation about the Heavenly mandate, while disregarding its relevance for the dynastic cult of state and the elevation of the emperor as the Son of Heaven (Tang, Renwen jingshen zhi chongjian, p. 421). The latter aspects had been rendered obsolete by the founding of the republican state.

23 For the manifesto of 1958 on this point, see Zhang, Zhongguo wenhua yu shijie, p. 39.

24 For Mou's reference to "Confucian rationalism" and "new outer king" see Mou, "Cong rujia de dangqian shiming shuo Zhongguo wenhua de xiandai yiyi," p. 312. For Mou's concept of "new outer king;" also cf. Mou, Zhengdao yu zhidao, pp. 15, 20-21 (introduction to the new edition). 
(a typical feature of Western-style democracies) with a harmonization of political contestation through renewed "rites," i.e. ethical values and virtues. ${ }^{25}$

Like Xu Fuguan, Mou Zongsan and Tang Junyi left no doubt that traditional Confucianism had failed to produce a liberal democracy out of its own resources. As a result, a justification of liberal democracy in terms of a renewed, modern Confucianism was necessary if the introduction of democracy to China was not to spell the end of Confucianism as a political and social force. In this context, it is instructive to refer to Richard Rorty's characterization of the relationship between democracy and philosophy. Rorty identified, on the one hand, a strand of theories that try to provide liberal democracy with a comprehensive philosophical justification. These theories, among them communitarianism, assume political institutions can be no better than their philosophical foundations. On the other hand, Rorty pointed to a strand of theories that is represented by pragmatism as understood by Dewey and Rorty himself, which denies the need for any comprehensive philosophical justification of (American) democracy. At most, democracy might need some kind of philosophical articulation, though a full justification through philosophy might even be harmful to it. ${ }^{26}$

Tang Junyi's, Mou Zongsan's, and Xu Fuguan's modern Confucianism belongs to the first strand of theories identified by Rorty. Neither Mou and Xu, who were in Taiwan during the 1950s, nor Tang, who was in Hong Kong at the same time, could describe and analyze a liberal democracy from within the system itself. Instead, they had to anticipate its workings as well as its problems, and rely

$25 \mathrm{Xu}$, "Rujia zhengzhi sixiang de gouzao ji qi zhuanjin," pp. 59-6o. Xu was convinced that a "true" democracy which rested on a secure ethical foundation could be achieved only on a Confucian basis: ibid., pp. 53-54. For Xu, the substitution of the use of political power and the enforcement of law for the rule of virtue was not merely an ideal or limit-concept, but a historically realizable possibility; ibid., p. 5o. For a critical assessment of Xu's position, see He, “Rujia yu xiandai minzhu," p. 147; Xiong, "Xu Fuguan lun minzhu zhengzhi," p. 49.

26 Rorty, "Der Vorrang der Demokratie vor der Philosophie," p. 82. Rorty identified Robert Bellah, Alasdair McIntyre, Michael Sandel, Charles Taylor, and the early Roberto Unger as communitarians; ibid., pp. 85-86. Given Rorty's persuasive interpretation of Dewey's pragmatism as fundamentally different from communitarian approaches to liberal democracy, analogies between Confucian political thought and a "communitarianized" Dewey seem problematic. A differentiation of political theory somewhat similar to Rorty's can be found in Ernst Vollrath's Grundlegung einer philosophischen Theorie des Politischen, albeit in the context of comparing the development of Anglo-American and German political theory. Vollrath's analysis is in reference to Hannah Arendt's attempt to develop a concept of power of political judgement out of an interpretation of Kant's third critique. 
on their observations of non-Chinese democracies. Where American philosophers can look back on the history of American democracy to understand the formation of political judgment, modern Confucians of the second generation had to make conjectures about almost everything that was related to liberal democracy. And while Rorty was not thinking specifically of Confucian philosophers, his approach is still helpful in describing their thoughts on democracy. Their political thinking starts from strong religious-metaphysical assumptions about the nature of man. In view of Rorty's juxtaposition of philosophy and democracy, they can therefore be labeled as "philosophical" in a broad, foundationalist sense. For them, it was pivotal that their modern reconstruction of Confucianism entailed a comprehensive philosophical, or, in the case of Tang, civil-theological justification of democracy.

\section{The Weakness of Democracy in China}

Tang's thoughts on a Chinese democracy and his above-mentioned examination of the reasons for the absence of a modern nation-state in China are closely related. But it was the communist victory on the Chinese Mainland in 1949 that formed the immediate historical context for his reflections about political democracy. Tang apparently presumed that the communists would not have succeeded in conquering the Mainland if there had been a modern nation-state, complete with a democratic constitutional order. In an article dated September $195^{\circ}$ and entitled "The Cultural Background of China's Contemporary Chaos," ${ }^{27}$ Tang analyzed the failure of democracy after the foundation of the republic in 1912. During the 1950s, he published a number of texts dealing with the same question, among them: "Basic Knowledge about Humanistic Culture and Democracy,"28 "The Humanistic and Democratic Spirit in Chinese and Western Societies,"${ }^{29}$ the Confucian manifesto of 1958, and the monograph Cultural Consciousness and Moral Reason, which was published in the same year. Tang clearly assumed that this search for the roots of the problem should precede any attempt to anticipate the requirements for a future Chinese democracy.

27 Tang, Renwen jingshen zhi chongjian, pp. 260-281.

28 Published in Democratic Review (Minzhu Pinglun), Vol. 3, No. 24 (February 1952); see Tang, Renwen jingshen zhi chongjian, pp. 388-401.

29 Published in Democratic Review (Minzhu Pinglun), Vol. 4, No. 4 (February 1953); see Tang, ibid., pp. 402-425. 
In order to present a balanced examination of the related shortcomings in China's political history and Chinese political thought, Tang did not neglect to discuss (contingent) historical developments that worked to foreclose the formation of constitutional democracy in China, even though he placed more emphasis overall on intellectual issues. The manifesto of 1958 rejected the view that solely the lack of democratic ideas in traditional Chinese political thought was to blame for China's failure to develop a democratic government. The manifesto reminded its readers that the final failure of democracy in China in 1949 was mainly due to actual developments in political history, such as the high tide of nationalism and the failure of reforms under the government of the GMD after the Japanese intrusions in the early 1930s, the Second World War, and the ensuing civil war. Most importantly, the government of the GMD had been unwilling to establish a democracy after the successful military unification of the country in 1928 and instead implemented a single-party government under the guise of a so-called political tutelage. ${ }^{30}$

These turns of events happened in the aftermath of the republican revolution in 1911 which, according to the manifesto of 1958, was not so much a victory of democracy as a success of anti-Manchu Han nationalism. The manifesto consequently suggests that the founding of the republic had been widely perceived by the Chinese as just another dynastic change, even more so since there were no clear ideas of popular sovereignty, democracy, and political rights among the population. ${ }^{31}$ The authors of the manifesto concluded that given such a weak presence of democratic ideas before and after 1911, it was not surprising that communism gained wide currency at the expense of democratic thought-especially given China's historical experience with an "invasion at the hands of Western capitalism and the repression by imperialism."32 The absence of a democratic government in China was thus not entirely due to the peculiarities of political thought in pre-2oth century China, but also a result of the unpredictable course of Chinese history since the mid-19th century. Besides this, Tang also took geographical and demographical aspects into account, such as the size of China's population and territory, and referred the reader to a broad historical context of pre-imperial and imperial China. ${ }^{33}$

The gist of Tang's analysis, however, deals with the social structure of late imperial China and the social background, the mentality, and the intellectual preferences of the social and political elites. The focus lies here on develop-

\footnotetext{
30 Zhang, Zhongguo wenhua yu shijie, pp. 42-43.

31 Ibid., p. 41.

32 Ibid., p. 43.

33 Tang, Renwen jingshen zhi chongjian, p. 420.
} 
ments and constellations in China which stand in stark contrast to the historical evolution of Western democracies. Particularly important is the historical formation of an elite mentality that ultimately prevented an engagement with democracy. With this in mind, Tang called attention to political and economic issues such as the fact that there had been no feudal aristocracy in imperial China. He, moreover, highlighted the weak accumulation of large amounts of capital in commerce since the Han Dynasty, the difference between traditional Chinese associations of commerce and the more autonomous guilds in Western countries, the traditionally low social prestige of merchants in imperial China, the absence of an autonomous class of landowners since the Sui and Tang Dynasties, the absence of a capitalist class in modern China, and the traditional detachment of farmers, craftsmen, and merchants from politics. In addition, he mentioned the inability of clerical organizations in traditional China to dominate the state and society in a manner comparable to Christian churches. ${ }^{34}$ Thus, whereas Western democracies gradually took shape in societies which were stratified by an aristocracy, powerful families and land owners, clerical organizations, and eventually by the process of industrialization, leading to the formation of labor organizations, late imperial China did not see such developments. ${ }^{35}$

As for the educated elites in China and their particular mentality-in Tang's terminology their "spirit" (jingshen)—he concluded that they had mainly evolved since the Tang and Song Dynasties in the context of the imperial civil service examinations. Accordingly, unlike their Western counterparts, modern Chinese intellectuals did not emerge from the church, the aristocracy, the landowners, or, finally, the petty bourgeoisie. ${ }^{36}$ As a consequence of this social-historical setting and the mentalities it shaped, the predominant ideal for the educated person in China was to shoulder the responsibility for the whole ecumene (tianxia). This ideal required the educated to refrain from representing politically the interests of a specific class, social organization, or church. Instead, non-partisan participation in politics became, at least in theory, one of the guiding ideas of an elite culture wrought by the civil service system of imperial China. In the post-revolutionary political environment of the republic, this mentality proved to be very harmful, as the intellectuals who had already lost their traditional vitality now contented themselves with representing their personal "individualism." ${ }^{37}$ Members of the intellectual elite,

\footnotetext{
34 Ibid., pp. 270-271.

35 Ibid., p. 272.

36 Ibid., p. 270.

37 Ibid., pp. 270-271.
} 
including those who acted as members of parliament, now had the mentality and the social background of free-floating intellectuals and academics. Unlike members of parliament in Western countries, they represented neither specific class interests, nor particular professional groups or religious organizations. They were thus not swayed by social or economic forces and their political position was weak. At the same time, they remained aloof to social reality. Their speeches and actions were not regulated or restricted by any social, economic, or clerical clientele, nor were there political parties powerful enough to exert a system of checks and balances in parliament. ${ }^{38}$

It is against the backdrop of this depiction of late imperial and early Republican China that Tang reflected on the impact of Confucian humanism on the evolution of democratic ideas. He was, as we have seen, highly critical of Confucianism's political traditions, but he did not reject its humanist strands. His analysis is indeed nuanced, as evidenced by his statement that before 1911, “[ $t$ ]he humanistic spirit of China's past contained a democratic spirit, but there were no institutions of democratic politics in the Western style." ${ }^{39}$ The Confucian "humanistic spirit" is thus identified as an intellectual resource of democracy in China. As for the democratic function of this spirit, Tang was convinced that it was manifest in the great importance which Confucianism placed on the personality of individuals. ${ }^{40}$ This facilitated - if we are to follow the interpretation from the manifesto of 1958 - the establishment of meritocratic ideas and institutions in imperial China.

Although meritocratic elements, which were predominantly related to the notion of a government by virtuous and able persons, ${ }^{41}$ are part of an "ideal" democracy, they were, according to Tang, severely flawed. First of all, there was no persistently effective safeguard against the abuse of power by the rulers, even though some meritocratic measures and institutions had been established, such as the civil service examination system, which was open to competition for parts of the male population; a sort of cabinet in the government, which not only counseled the emperor but at times would remonstrate against him; the so-called censorial system, which functioned to survey and admonish the officials as well as the emperor himself; and the institutional-

38 Ibid., pp. 270-271; see also Zhang, Zhongguo wenhua yu shijie, p. 41.

39 Tang, Renwen jingshen zhi chongjian, p. 420; see also ibid., p. 413. For a similar statement, see Tang, Wenhua yishi yu daode lixing, pp. 289-291: Here, Tang concluded that there was no rule of law in Chinese history comparable to the development of the rule of law in the West.

$40 \quad$ Tang, Renwen jingshen zhi chongjian, p. 416, also cf. p. 413.

41 Tang, Wenhua yishiyu daode lixing, pp. 288-289. 
ized production of a historiography which passed posthumous judgments on emperors and dynasties. These institutions, however, proved to be inefficient when it came to preventing or at least sanctioning serious abuses of power. Ultimately, the quality of the political order depended on the willingness of those in power to abide by meritocratic ideals. ${ }^{42}$

Not only were the institutions of meritocracy deficient, but the idea itself was fundamentally flawed. A truly virtuous ruler would certainly encourage his subjects to reinforce their moral personality, but since the subjects depended on exemplary rulers and were, in fact, for the most part denied political participation, they would never attain sufficient autonomy to actualize their moral subjectivity. ${ }^{43}$ Tang therefore concluded that the Chinese spirit of democracy was present only in the "moral spirit" of Confucianism, and thus in a "hidden" form that never amounted to the manifestation of a "political spirit." Consequently, the Chinese people were not aware of their status as political subjects and had no conception of any claim to political rights: ${ }^{44}$

I say that Confucian thought contains the highest democratic spirit, because [Confucian thought] believes in the highest sense that every human being can become a sage and join Heaven in virtue. Now people may ask: Why didn't Confucians talk about Western style democratic politics...? (...) My answer is: Originally, Confucians took politics just as a direct extension of morality; politics was [thought of as an] occasion for the direct realization of human moral consciousness. ${ }^{45}$

In the same vein, Mou Zongsan and Xu Fuguan critically reflected on the absence of "political subject[ivity]" (zhengzhi shang de zhuti 政治上的主體), to use Xu's term, from traditional Confucian political thought. As Xu maintained, this was the downside of the Confucian conflation of politics and ethics, which essentially resulted in the supplanting of political subjectivity by moral subjectivity. ${ }^{46}$ Tang, too, left no doubt that the reason for the lack of subjectivity had to do with Confucianism itself. In particular, he was concerned,

42 Zhang, Zhongguo wenhua yu shijie, pp. 37-38; see also Tang, Wenhua yishi yu daode lixing, p. 289 .

43 Zhang, Zhongguo wenhua yu shijie, pp. 38-39.

44 Tang, Renwen jingshen zhi chongjian, p. 420.

45 Ibid., p. 419; also cf. p. 422.

$46 \mathrm{Xu}$, "Rujia zhengzhi sixiang de gouzao ji qi zhuanjin," p. 55. On Mou, see my "Confucian Democracy' and its Confucian Critics: Mou Zongsan and Tang Junyi on the Limits of Confucianism," pp. 177-183. 
as we have seen, with the inability of pre-modern Confucianism to reach an adequate understanding of the lust for power that is deeply rooted in human nature. Unlike Xu Fuguan, he argued that since Confucian philosophers had failed to develop an adequate political anthropology, they held on to a false belief in the potential of individual character-building and education, and thought this would be sufficient to contain the human lust for power. They did not recognize, in other words, how deeply rooted this desire is in human nature. Consequently, they settled for a political philosophy that treated political power mostly in terms of educational efforts directed at individuals, including the rulers, who were expected to cultivate their moral natures. ${ }^{47}$

\section{The Civil-Theological Justification of Democracy}

Tang's justification of democracy is based upon an idea of man which is closely intertwined with his Confucian civil theology. A key element of the civiltheological idea of man is the assumption of an indissoluble human lust for power. Because the political traditions of Confucianism severely misjudged the latter, Tang denied that pre-modern Confucianism was suited for bolstering the call for constitutional democracy. After all, with respect to democracy, one needed to account for the human being's persistent lust for power:

What makes democratic politics a necessity is indeed that human beings have a political consciousness stemming not only directly from [their] moral consciousness, but also from a drive for power. This means a government of sage-kings or Plato's philosophers can almost certainly not appear in reality. If such [government] would [actually] appear, it would not be able to objectively guarantee its continuation. ${ }^{48}$

Among the indispensable arrangements to prevent the abuse of political power, Tang deemed the institutions for legislation and public elections to be especially important. This entailed a system of checks and balances which would gradually reduce the likelihood that political wills destroy "the values of human existence and culture." 49 Tang thus justified democratic institutions-

47 Tang, Renwen jingshen zhi chongjian, pp. 395-396, 422.

48 Ibid., pp. 394-395. Since this political anthropology is fundamental to Tang's political philosophy, He Xinquan's (Ho Hsin-chuan) critique that Tang only partially separated politics from ethics is unjustified; see He, Ruxue yu xiandai minzhu, pp. 128-129.

Tang, Renwen jingshen zhi chongjian, pp. 396-397. 
in particular the democratic formation of the political will—by stating that they effectively balance and mitigate the wills for power. It is also significant that he conceptualized the necessity to curtail dangerous power struggles without an accompanying call for a "new man" of higher moral qualities.

The justification for institutions of checks and balances is hence inseparable from the idea that individuals express their "political consciousness" by striving for power (i.e. by participating in politics). ${ }^{50}$ Tang's political thought takes a turn here which is untypical, to say the least, in Confucian traditions: His line of argument clearly suggests that something "good," such as a democracy, can arise from something morally questionable, namely, the latently evil lust for power which elicits the need to establish checks and balances. As he pointedly concluded, the source of democracy is not "perfectly holy." He therefore took issue with any political philosophy founded on an excessively optimistic belief in human goodness. ${ }^{51}$ Tang certainly resisted the lure of an ethics of conviction, favoring instead an ethics of responsibility. As a consequence, any justification of liberal democracy based on the assumption that the political consciousness of individuals might and should become a direct extension of their moral consciousness must be regarded, according to Tang, as inadequate and self-contradictory. The belief that the moral good can be readily detected and thereafter implemented given that political decisions are taken by a truly moral consciousness amounts, in fact, to a denial of the desirability of popular participation. Tang maintained that if the identification and implementation of moral truths were taken to be crucial criteria for decisions in politics, a monarchy (or an authoritarian system for that matter) in which a tiny minority of exemplary figures rules according to their presumably superior moral standards would have to be regarded as the best political system. ${ }^{52}$

Therefore, Tang did not justify institutions like the rule of law or public elections in terms of moral subjects, but rather in terms of the idea that individuals are universally entitled to claim rights for themselves:

The spiritual foundation of early modern Western rule of law and government by the people consists in the universal recognition of the rights of the people. This establishing of a principle of reason in recognizing everyone's rights can be said to originally come from each individual affirming and grasping their own rights, which [in turn] stems from human's selfish desires. Yet, each individual's affirmation of their own rights [in turn leads

$\begin{array}{ll}5^{0} & \text { Ibid., pp. 394-395, } 398 . \\ 5^{1} & \text { Ibid., pp. 396-397. } \\ 5^{2} & \text { Ibid., p. 394. }\end{array}$ 
to a situation where] the rights of all individuals constrain one another. From this, human beings attain the notion of transcending their individual rights and recognizing the rights of others. Thus, there is the establishment of the reasonable principle that the rights of all men should be recognized. (...) By establishing this principle of reason... everyone can observe the guidance this principle [provides] and become aware of their own reasonable self as it transcends their striving for rights, further nourishes and expands their moral will and completes their moral personality through self-awareness. (...) Only then may China's past ideals of government by virtue, government by [upright] men, and government by morals be truly realized. ${ }^{53}$

In other words, the contemporary realization of the ideal of "government by virtue" rests upon a much less optimistic view of human nature. It thus makes room for the political institutions of liberal democracy, which were inconceivable for Confucians of the pre-Qin and imperial centuries. As Tang suggested, the Confucian tradition provided an insufficient basis for the justification and stabilization of core institutions of liberal democracies such as the rule of law and the legal protection of human rights:

Here, the Confucian idea of the whole man as a cultural and moral being seems inadequate as the spiritual ground for the establishment of a modern community and modern vocational morality.... the modern ideas of human rights, as related with ideas of democracy, freedom, and equality, are all defined objectively in terms of the individual's social, political, legal, and economic relations to others. (...) Thus the human rights protected by modern laws are actually protected by the whole legislative system, which is related to the whole political and social systems and not protected merely by our subjective moral sense of justice. Here, we see that the Confucian idea of a moral sense of justice has never developed enough to build such a modern systems [sic]. The Confucian's idea of freedom is man's moral freedom to do the moral good. The Confucian's ideas of right and the equality of men are essentially the equality of moral nature and moral right to be sages. All of these Confucian ideas are not sufficient to provide a spiritual basis of modernization. To respond to the demands of the age, a further development of Confucianism from within is called for. ${ }^{54}$

54 Tang, "The Reconstruction of Confucianism and the Modernization of Asia," pp. 368-369. 
The question, then, is what role, if any, can a renewed, modern Confucianism play in the context of establishing a democracy in China? Given Tang's, as well as Xu Fuguan's and Mou Zongsan's, judgment about the ambivalent nature of Confucianism (on the one hand, it is an intellectual "sprout" of democracy; on the other, it is responsible for the failure to establish a democratic government before 1911), the issue becomes even more delicate. Addressing this problem was particularly important, because they considered a democratic nationstate to be modern Confucianism's authentic political form. They therefore needed to explain how democracy, constitutional government, and the rule of law can be understood and justified in terms of Confucianism. It was not enough to understand them as Western additions, as mere formalities added onto a Confucian ethical substance. After all, neither Tang nor Mou Zongsan and Xu Fuguan fell back on the pattern of 19th century Tiyong thought. Their concept of liberal democracy was not based on such simplistic notions. They also did not speculate about how to improve, or Confucianize, constitutional arrangements and institutional practices of extant Western liberal democracies. It was not their ambition to alter the form of liberal democracy even before it had begun its political life in China.

A fundamental assumption of Tang's, Xu's and Mou's transcultural political thought is that, in order to take root in modern China, Western institutions and ideas need to stand the test of a full justification in terms of indigenous philosophy. In this context, Tang Junyi delineated comprehensive "philosophical" approaches (to borrow Richard Rorty's term) to justifying democracy as those based on a theory of natural law and those focusing on a concept of the dignity of the individual. As Tang explained, he attempted to justify democracy by introducing the Mencian idea that every human being can "become a Yao or a Shun." He presumed that "becoming a Yao or a Shun" is a formula connoting that every individual, as a "moral subject" (daode de zhuti 道德的主體), has the same natural potency to become a "sage." All individuals should therefore also receive equal recognition as "political and social subjects" (zhengzhi shehui zhi $z h u t i$ 政治社會之主體). ${ }^{55}$ Accordingly, when discussing the ultimate goals of those striving for democracy and freedom, Tang singled out the idea of realizing the individual's (moral) nature, reason, and holiness. ${ }^{56}$

55 Tang, Zhonghua renwen yu dangjin shijie, Vol. 2, p. 45.

56 See his article from $195^{2}$ entitled "The Establishment of Chinese Democratic Thought" (“Zhongguo minzhu sixiang zhi jianli” 中國民主思想之建立) reprinted in: Tang, Zhonghua renwen yu dangjin shijie bubian, Vol. 10, p. 165. 
Tang did not develop a full-scale theory of democracy that deals with questions of political justice, legitimacy, or sovereignty in-depth. ${ }^{57}$ Yet one may still find some remarkable peculiarities in the democratic ideas that he enunciated on the basis of his Confucian civil theology. To begin with, there is the attempt to comprehensively integrate the idea of a renewed Confucian ethical life (including the "consciousness of rites") into the institutional setting of a liberal democracy. This entails, as we have seen, a "Confucian" interpretation of civic virtues such as solidarity and tolerance as manifestations of the individual's freedom to practice moral self-cultivation in the community. The democratic practice itself is hence said to provide impetus for the individual's moral self-cultivation. Moreover, democracy is deemed desirable because it allows individuals to engage in moral and spiritual self-fulfillment, and do so without risking their own survival in the political community along the way. Equally important, the striving of individuals to attain political power is not entirely curbed in a liberal democracy, nor is their pursuit of individual self-interest. From the perspective of modern Confucian civil theology, it is therefore possible for individuals to give expression to both their moral nature and their evil inclinations, albeit within legal limits. They can thus learn to judge for themselves whether their actions are morally questionable or not, and, in so doing, further develop their moral subjectivity. ${ }^{58}$

Based on his belief that individuals need to attain the freedom of expressing their natural endowments when striving for self-fulfillment, Tang identified liberal democracy as the political form best suited for the quest for self-fulfillment. Democracy can be understood as an institutional and procedural precondition, and at the same time as an ongoing political and ethical context for personal self-cultivation. Tang thereby abandoned the older notion of good government as depending on the virtuous quality and superior personality of the rulers. Democracy, in Tang's view, can work even if those in power are not virtuous, self-cultivated individuals. Citizens need neither qualify themselves by becoming moral beings, nor manifest their goodwill by engaging in self-cultivation and education:

57 Tang's notion of liberal democracy does not differ significantly from Mou Zongsan's; cf. Fröhlich, "'Confucian Democracy' and its Confucian Critics: Mou Zongsan and Tang Junyi on the Limits of Confucianism," pp. 177-183.

$5^{8}$ Tang, Renwen jingshen zhi chongjian, pp. 394-395, 398. On the meaning of politics in relation to anthropological-metaphysical assumptions of the original nature of human beings, see, ibid., p. 417. 
Therefore, the rule of law and democratic institutions are also [a way of] cultivating and nourishing ordinary people so that they are endowed with the self-awareness of the universal reasonable self. It is thus already sufficient if ordinary people do not overstep the limits set by the law in their affirmation and grasp of their own rights and in [their] struggle for rights with other people- - in this regard, they] cannot make a grave mistake either. (...) But the philosophers of China's past did not yet thoroughly understand this. .9

If citizens do not behave morally, it does not mean democracy is failing or unjustified. In other words, modern Confucianism should not justify political authoritarianism in the guise of pursuing lofty ideals of moral and spiritual education with ostensibly still immature Chinese citizens. Tang, therefore, departed from the authoritarian approaches to Confucianism by assuming that a democratic government neither needs morally superior sage-rulers, nor a model citizenry of exemplary, virtuous personalities. If politicians and citizens behave like morally advanced individuals, democracy would flourish, but it could also function if they are not morally superior persons. Clearly, Tang did not support the conflation of politics and ethics, which he saw as ever-present in the Confucian tradition, and in this sense his reconstruction of Confucianism is distinctly modern. Although Tang did not explicitly refer to Kant's distinction between a good, law-abiding citizen and a morally good individual, he followed a similar line of thought - in contrast, for example, to Xu Fuguan. ${ }^{60}$ Given Tang's distinction between good citizens and morally good persons, his rejection of the belief that sage-rulers or sage citizens are preconditions for a functioning democracy is not surprising. He was indeed content to conceive of a democratic community as a political and ethical context for an individual's pursuing "the perfection of [his or her] personality."

By conceptualizing the individual's being a sage as a fleeting moment of moral intuition, Tang's modern Confucian civil theology implied that an enduring, morally perfect human community cannot be attained and political reality cannot be turned into an earthly paradise. At the same time, Tang used the civil-theological limit-concept of selfhood as a sage to establish a critical distance from political life and avoid the danger of simply reaffirming the current political reality. The other side of the coin is that what individuals in the ephemeral moment of sagehood perceive as true, authentic, or correct is

59 Tang, Wenhua yishiyu daode lixing, p. 291.

6o For a critique of Xu's tendency to blur the conceptual distinction made by Kant, see Xiong, "Xu Fuguan lun minzhu zhengzhi," p. 51. 
internal to themselves and done without reasoning with other human beings. "Inner sagehood" is not a democratic figure, and nor could such a sage accept a political compromise. He would not submit to rule by the majority or to the idea that decisions are democratically valid, not because they are correct, but because the procedures of decision-making are a matter of agreement about that process in advance. A community populated only by sages would lose its political character altogether, and there would be no negotiating, no use of political power, and even no communication. There would just be a complete unity of "innate knowing" and behavior. This vision obviously transcends the realm of liberal democracy in a radical sense. To be sure, neither Tang Junyi nor Mou Zongsan expected such a community would ever become a historical reality. The community of sages is real only insofar as it is part of the civil-theological justification of democracy. It is neither the highest ideal of democracy itself, nor its ultimate historical form. In spite of this limitation, the justification of democracy in terms of this limit-concept poses two problems in particular:

(1) The persuasiveness of arguments in favor of liberal democracy rests on the religious-metaphysical assumptions of modern Confucianism's civil theology. That means a shared belief and social acceptance of Confucianism as a form of religious humanism (or civil religion) is crucial to the justification. This does not necessarily mean religious freedom would be endangered, since Confucian religious humanism is not a ruling ideology bolstered by constitutional provisions. Moreover, it could be argued that a Confucian civil religion can also tolerate other forms of religion. But if we understand modernity today in post-metaphysical terms, things look different. Even if it were possible for Confucianism to develop into a civil religion - a highly problematic and questionable prospect - what would happen if Confucianism (as religious humanism) gradually lost its appeal as social change occurs? Is there some underlying rationale for dealing with a plurality of justifications? And would that rationale have to be justified in terms of Confucianism?

(2) The civil-theological justification paradoxically points towards the complete dissolution of democracy. After all, there is an implicit tendency to portray democracy both as a precondition or a context and as a means to the (apolitical) higher end of self-fulfillment as a sage. The problem is not so much that democracy is seen as a means, since this is asserted in other political theories, including Western theories, without undermining the existence of democracy. The problem is that Tang assumed that the end to which democracy is supposed to lead (i.e. the sphere of the sage) is settled beyond the sphere of politics, making democracy as means not just optional, but accidental. Consider the rationality of the procedures of democratic decision-making in terms of 
Confucianism: In the course of discussing political issues, in the framework of democratic rules, participants following those rules not only identify themselves as citizens or politicians who accept procedural agreements of democratic decision-making. They also represent themselves as human beings who have not attained "inner sagehood," and are thus in need of self-cultivation. There would otherwise be no reason for discussion, since the sages intuitively know the one truth without prior communication. From a Confucian point of view, participating in a democratic debate, and in so doing respecting the opinions of others, is conducive to one's self-cultivation. Starting a fistfight is not. But how does one know that this is true? The foundation of this knowledge cannot consist of a conceptually or otherwise symbolically represented form of cognition, because such a form of knowledge would function vis-à-vis one's ultimate, intuitive insight merely as a means. It is consequently a matter of belief that abiding by democratic rules and having a democratic attitude could be conducive to attaining the intuitive insights of a sage. But the same could be said of any form or technique of self-cultivation. If one does not share this belief, the civil-theological justification of liberal democracy loses its appeal. As a result, the precarious conceptual foundation of democracy would be laid bare: it would float between the two poles of a concept of the political sphere marked by the individual's irrational lust for power, on the one hand, and the notion of an individual's spiritual inwardness culminating in an irrational intuition, on the other. It is the destruction of rationality in (democratic) politics that looms large at this point.

The crucial question, in the end, is what function this justification has relative to the workings of a liberal democracy. If it is considered fundamental, in the sense that democracy can only work if everyone, or at least a majority, shares these Confucian convictions, then the old trap of dogmatism is set again. This is not what Tang had in mind. He clearly stated the priority that a constitution and the rule of law must have over continuing the political traditions of Confucianism. Modern Confucianism would thus be one among many other intellectual or religious resources for reproducing civic virtues and democratic convictions among the citizens. Reading Tang Junyi (and Mou Zongsan), though, one cannot help but feel that what he actually wanted was a far more prominent role for Confucianism. Just the same, at least until the mid-196os, Tang and Mou resisted the lure of Confucian authoritarianism. Besides, it is no contradiction that they were simultaneously both ardent cultural conservatives who emphasized the importance of Confucianism, and political liberals who insisted on legal guarantees for political pluralism and religious freedom. Their cultural conservatism was a kind of outlet for their high expectations of Confucianism. They had to politically moderate those expectations in order 
to fulfill what they perceived a democratic modern China would require. This was, of course, part of a discourse on democracy that is proleptic in character: Tang argued for the effectiveness and the desirability of a type of democracy which had not yet emerged in Chinese history.

\section{Humanistic Culture and Democracy}

According to Tang Junyi, democracy does not solely rest on constitutional institutions and procedures, but also on individual attitudes, virtues, and values deemed favorable for sustaining a democratic order. Tang indeed avoided a highly formalized conceptualization of constitutional democracy which would preclude any elements of a value-rational justification. Instead, he understood the practice of democracy to include virtues, values, and habits of individuals who conform to the rule of law voluntarily, and not solely due to heteronomous legal force. ${ }^{61}$ The ethical and cultural preconditions of democratic government do not exclusively pertain to the realm of the individual, but also to the collective sphere of social and cultural life. In order to effectively meet the requirements for democracy, "the position and dignity" of the individual must be given "objective political meaning." ${ }^{2}$ This will take place, as Tang explains, in a "social atmosphere" (shehuifengq $i$ 社會風氣) that allows the individuals to develop an awareness of the "humanistic world."63 For one, such a social environment entails the formation of a public opinion that holds "personalities from [the sphere of] society," such as entrepreneurs, scholars, educators, and those engaged in charitable work, in equally high esteem as politicians. ${ }^{64}$ Hence, not only the recognition of political roles in the narrow sense matters to political life, but also the recognition of social and cultural roles.

Tang posited here, in fact, that the individual quest for recognition is a core element in political, social, cultural and economic life, even though the forms of recognition and the means to achieve it may differ. This claim corresponds, as we have seen, to the analysis of the lust for power as driven by the individual's desire to gain recognition from others. From the perspective

\footnotetext{
61 On this topic, see Tang, Zhonghua renwen yu dangjin shijie, Vol. 2, p. 105.

62 Tang, Renwen jingshen zhi chongjian, pp. 401, 423-424. Tang refers in this context to "humanistic forces" (ibid., p. 423) and to "social and cultural forces and organizations" (ibid., p. 401).

63 Tang, Zhonghua renwen yu dangjin shijie bubian, Vol. 10, p. 237.

64 Tang, Renwen jingshen zhi chongjian, p. 424.
} 
of power politics, the willingness to recognize others as rulers is due to the suppression by an opposing will. As regards the victorious will, it would take its self-exhaustion and subsequent "reversal" in the "great emptiness" to turn it into a moral will that voluntarily recognizes the will, personality, or value orientations of others (see Chap. 7). Even the individual's deepest absorption with the lust for power hence still provides a possibility for non-coercive recognition. In turning to political life in a democratic society, we may conclude from this analysis that although power struggles may prevail, there is still a measure of voluntary recognition to be expected from political actors. At this point, Tang's political thought takes an almost existentialist turn. His reference to the individual's reversal in the great emptiness indeed suggests that beyond the forms of legally enforced and voluntary recognition, there is an existential ground for recognition.

In spite of his focus on the issue of recognition in social interaction, Tang appears to have not devised a theory of recognition that differentiates between recognition among abstract legal subjects, individuals in ethical relations, or collectivities within social sectors. It is, therefore, more apt to say that Tang established a foundation for further theoretical reflection about issues of recognition, without pursuing such a path himself. But even so, he clearly arrived at the conclusion that struggles for recognition were as pervasive in political, power-driven interactions as in social and cultural interactions. We may further conclude that if the members of a democratic community have sufficient opportunities to become immersed in the "humanistic" realm of recognition, they might eventually become more inclined to voluntarily recognize other individuals and their value orientations. This, in turn, would have the effect of mitigating power struggles and reducing the need to resort to legal force as a means to sustain democratic practice and order.

In the same vein, Tang warned against the tendency to perceive politics and political life in general solely in terms of power struggles. ${ }^{65}$ Such a misguided perception would preclude the awareness that the "original" motivation for political acts indeed stems from a "mind of humaneness and justice," which facilitates forms of voluntary recognition. Rather enigmatically, Tang claims that this reflection about the motivation to pay recognition is concerned with a psychological fact. ${ }^{66}$ But what about the will for power as a driving force of political activity? As we have seen, Tang considered the will for power to be "original," too. The coexistence of the "mind of humaneness and justice" and the will for power at the motivational origin of political activity seems to

65 Ibid., p. 424.

66 Ibid., pp. 391-392. 
be an uneasy one. However, they are not necessarily unrelated to each other. Tang had tried to show in his analysis of the will for power that it operates dialectically, undergoing a reversal into a moral will. What is more, the "mind of humaneness and justice" does not have to be understood for it to completely lack a will for power. Be that as it may, Tang was certainly not saying here that political life may be cleansed from all power-seeking action and motivation. He rather wanted to highlight that the concept of politics must not be reduced to a definition in terms of struggles for power, domination, and rule. The practice of civic virtues, tolerance, and solidarity that entails the willingness to pay voluntary recognition in political life is also to be considered political in an original sense.

On this basis, Tang argued that humanistic issues matter to political life in a democracy. He further assumed that the "spirit of humaneness and justice" essentially evolves within a humanistic realm composed of the spheres of ethics, religions, science, literature, art, education, and the economic sphere. ${ }^{67}$ As he saw it, these spheres belong to the so-called humanistic territory of collective life. ${ }^{68}$ By acting in these humanistic fields, the individuals are said to practice virtues and values and develop habits of voluntarily recognizing the personality and the value orientation of others. The humanistic realm in society was obviously not to be confounded with an apolitical realm for the retreat of individuals into a spiritual or religious inwardness, but should contribute to the normative preconditions of democratic political order. Tang emphatically stated that "all thinking and concepts in politics" should be related to humanistic thought and concepts, and this was also to pertain to the concept of democracy which had to be interpreted from the perspective of humanistic concepts. ${ }^{69}$

According to Tang, in terms of their relevance for the social formation of a non-coercive practice of recognition, the sciences and the economic sector should be set at the periphery of the humanistic core area of ethics, religions, literature, art, and education. Politics, on the other hand, is only to have "subordinated" relevance. ${ }^{70}$ This outlook entails the assumption that the willingness of individuals to voluntarily recognize "values of human existence and culture," i.e. the value orientation, personality, and dignity of others, results from the individual's immersion in the humanistic core area. At the same time, this willingness is to form the normative basis for the political consciousness of

\footnotetext{
67 Ibid., pp. 403, 409-410.

68 Ibid., p. 403.

69 Ibid., p. 388.

70 Ibid., pp. 63-66.
} 
citizens in a democratic society. ${ }^{71}$ It is with this rationale that Tang identified China's "humanistic spirit" in general and the "Confucian spirit" in particular, which holds the individual's personality in the highest esteem, as the spiritual foundation of democracy. ${ }^{72}$ It should be kept in mind here that Tang was, as we have seen, convinced that any Confucian renewal of the individual's ethical life and his or her ethical disposition (i.e. a "consciousness of rites") in turn required the practice of constitutional government and the rule of law.

Tang's reflections about issues of recognition in a democracy may seem to remain somewhat nebulous, because he neither bolstered them with a comprehensive political ethics, nor with a political axiology that might clarify the hierarchy and inter-relatedness of political values. Even so, he obviously considered the individual's ability to evaluate "political personalities" on the basis of a hierarchy of political values as a key competence of citizens in a democracy. He referred to the period of the founding fathers of the United States as being exemplary for this civic competence. In the early period of the republic, the Americans are said to have still "cultivated" a "spirit of striving for higher [values and virtues]" together with the willingness to make personal sacrifices for the sake of the republic. ${ }^{73}$ In order to preserve such a civic mindset under conditions of a progressive modernization (within a future Chinese democracy), it would be necessary to accord key relevance to a humanistic core area which must, consequently, be shielded from a thorough politicization or economization. Tang was not overly optimistic in this regard, as he bluntly stated that historical developments in the United States showed how, at the stage of advanced industrialization and increasing division of labor, the danger of a domination by "instrumental values" (gongju jiazhi 工具價值) ${ }^{74}$ was growing and with it a general leveling in value orientations. The existence of a humanistic core area within modernizing societies was thus not only threatened by ideational factors such as a misguided reduction of politics to power struggles, but also by factors pertaining to the socioeconomic, structural conditions of modernization that tend to undermine the civic consciousness in a democratic community. ${ }^{75}$

71 Ibid., pp. 391-392. Tang related this to the Confucian worthies who allegedly made humaneness and justice their "basis" for recognizing values of human existence and culture. According to the "teachings of the goodness of [human] nature," all human beings are capable of such recognition; ibid., pp. 416, 418.

72 Ibid., p. 416. This is the political meaning of the proposition from the manifesto of 1958 according to which the Confucian "study of mind and [human] nature" was at the "heart" of Chinese culture and scholarship; see Zhang, Zhongguo wenhua yu shijie, p. 21.

73 Tang, Zhonghua renwen yu dangjin shijie, Vol. 2, pp. 134-135.

74 Ibid., p. 134.

75 Ibid., pp. 132-134. 
If Tang had been an American political thinker, he might have belonged to the tradition of the liberal left. Both his concept of a humanistic core area within a democratic society and his notion of a renewal of traditional "communities and associations of alumni, of members from the same birthplace, of academics, of participants of poetry and wine gatherings" under conditions of social modernity roughly correspond to John Dewey's conception of a "Great Community." ${ }^{\text {"6 }}$ Dewey assumed that given the evolution of modern mass communication and the ensuing emergence of a badly informed, politically disinterested mass public, the participation of individuals in "lesser communities" (e.g. neighborhood communities) and local associations should play an important role in politics, because, as members of such communities and associations, individuals could gain experience in political participation. Dewey thus stated that, after all, "[d]emocracy must begin at home, and its home is the neighborly community."77 At the heart of this idea, there is a concept of the individual which more or less accords with Tang's concept. Dewey, too, assumes that

an individual is nothing fixed, given ready-made. It is something achieved, and achieved not in isolation, but [sic] the aid and support of conditions, cultural and physical, including in 'cultural' economic, legal, and political institutions as well as science and art. ${ }^{78}$

${ }_{76}$ Dewey refers in his book The Public and its Problems from 1927 to the pre-modern type of family and neighborhood associations of "the Orient," claiming that these were neither political communities nor part of the societal sphere. According to Dewey, such familial communities were ruled by "personal loyalties" and politics were "submerged in morals," while the "theocratic state" was considered to be remote. As a result, "[t]he intimate and familiar propinquity group [was] not a social unity within an inclusive whole;" see Dewey, The Public and Its Problems, pp. 41-42. Tang might have agreed. After all, when proposing to link up with the tradition of Chinese communities and associations, he did it on the basis of his diagnosis that there had been neither a civil society nor a modern nationstate in imperial China. Tang's position is therefore not in obvious contrast to Dewey's judgment. Tan Sor-hoon recently took a different approach and refuted Dewey's analysis with respect to pre-imperial and imperial Chinese (especially Confucian) thought: Tan, Confucian Democracy, pp. 122-123.

77 Dewey, The Public and Its Problems, pp. 210-213. On this issue in Dewey's thought, see Kallscheuer, "Pluralismus, Universalismus, Hermeneutik," p. 225; see also Kallscheuer, "Ein amerikanischer Gesellschaftskritiker. Michael Walzers kommunitarer Liberalismus," pp. 140-144.

78 Dewey, "The Future of Liberalism," p. 227; see also Kallscheuer, "Ein amerikanischer Gesellschaftskritiker. Michael Walzers kommunitarer Liberalismus," p. 141. For a discussion of the similarities between Dewey's concept of the individual and pre-imperial 
However, the similarities between Tang's modern Confucianism, on the one hand, and Dewey's political philosophy and other strands of American and European traditions of republican thought, on the other, should not be overstated. Modern Confucianism and Western republican traditions are based on vastly different theoretical frameworks. There are, for example, clear differences between Dewey's concept of liberty which states that liberty is the “... fulfillment of personal potentialities which take place only in rich and manifold association with others,"79 and Tang's theory of freedom which is based on the civil-theological notion of the self-fulfillment of personal potentialities as endowed by Heaven. These different points of departure entail vastly different ideas about the practice of individual self-fulfillment and the meaning and relevance of inter-subjective contexts.

Another difference pertains to the concepts of political reason which lie at the basis of the reflections about constitutional democracy. Anglo-American traditions of political thought in general take the long-standing experience with constitutional government as a crucial historical precondition for the formation of political reason, no matter whether constitutional government was republican or monarchic in nature, or whether there was a written system of constitutional law or a tradition of common law that did not produce written constitutions. In any case, political reason appears to be shaped by the reflection about the political history of one's "own" constitutional government. The formation of political reason and sound political judgment is thus seen as depending on the interpretations of the constitutional and political history, and not so much on philosophical speculation. In contrast, the latter flourishes when a long-standing, dominant tradition of constitutionalism is unavailable in one's own historical context. Political thinkers consequently try to tap more speculative sources of political reason. ${ }^{80}$

Tang Junyi's attempt to devise a civil-theological basis for political philosophy can be considered a typical case of the speculative mode of political thinking. Tang was, after all, in no historical position to refer to a time-tested,

Confucian concepts of human nature (xing); see Tan, Confucian Democracy, pp. 25-32, 50-53, 101-102.

79 Dewey, The Public and Its Problems, p. 150.

80 Vollrath considers the mainstream of 19th-century and early 2oth-century German political thought as a case in point. On his comparison between German and Anglo-American traditions, see Vollrath, Grundlegung einer philosophischen Theorie des Politischen, pp. 140-148, 159-16o. In this context, Vollrath deems it significant that studies in political history and political biographies are particularly prominent within Anglo-American political thought: Ibid., p. 148. 
indigenous tradition of constitutional government, as there was no such tradition in China's political record. It indeed seems to make a great difference whether political thinkers are forced to anticipate constitutional democracy or whether they can critically reflect on it while actually living in a political community that is generally described as a constitutional democracy. A pragmatic, non-speculative type of political thought which is skeptical about philosophical attempts to construct a theoretical foundation for political reason and truth claims has therefore literally been out of reach for Chinese theoreticians of the 2oth century. Given this intellectual-historical context, it is perhaps little surprising that Chinese political thinkers like Tang Junyi focused on a conceptual juxtaposition between (humanistic) culture and the lesser realm of politics. ${ }^{81}$ This again stands in stark contrast to Anglo-American traditions of political thought which conceptualized culture (or "civilization") to encompass the whole realm of political experience.

In order to deflect, on a conceptual level, tendencies to politicize the humanistic core of society, Tang developed a concept of politics that circumscribes the function of politics with respect to the social recognition of values and value orientations. Politics is hence said to have an indirect bearing on the deliberations and value orientations in public life. Tang explicitly referred to the American, British, and German post-war democracies in this context and explained that politics in general and political power in particular should be restrained, on the basis of constitutional law, by public opinion, social education, and economic forces. Such "restricted politics" (xianzhi zhengzhi 限制政治) would be confined to a “mediate form" (jianjie xingtai 間接形態), which would preclude an immediate, totalizing politicization of society. ${ }^{82}$

Tang further elucidated his concept of politics by comparing the function of politics, in a manner similar to differentiation theory, to the role of a policeman who is standing guard at the entrance of a theatre. The policemen thus facilitates the realization of (humanistic) social and cultural values (inside the theatre), but he does so "indirectly," without participating in the theatre performance itself, neither as spectator nor as a critic. ${ }^{83}$ Consequently, the "active tasks" to be fulfilled in politics, for example in the field of educational, cultural, or social welfare policy, are mainly to entail the task of organizing extant

81 Such a constellation is reminiscent of similar juxtapositions of culture and politics in German conservative thought of the late 19th and early 2oth century. On the German concepts of culture, civilization and the political, see also Vollrath, "Zur Problematik eines Begriffs des Politischen," pp. 321, 329.

82 Tang, Zhonghua renwen yu dangjin shijie bubian, Vol. 10, p. 237.

83 Tang, Renwen jingshen zhi chongjian, p. 39o. On this aspect of Tang's concept of politics, see also Liu, "Tang Junyi de zhengzhi zhexue," pp. 50-51. 
social, cultural, and intellectual currents. Here, too, politics is to be understood primarily as a means. ${ }^{84}$ It should hence be limited to a "domain" (lingyu 領域) within culture and society and must not be conceptualized as permeating the social and cultural domains. ${ }^{85}$ According to this conceptual strategy, politics itself is neither a sphere in which humanistic culture is produced, nor should politics take responsibility for making judgments about specific normative contents of humanistic culture. The foremost task of politics is to safeguard humanistic culture on the whole and in so doing prevent democracy from deteriorating into a combat zone of ideologies.

The confinement of politics to the function of safeguarding normative resources for democratic deliberations also has consequences for the role of political parties and politicians. Tang suggested that in a democratic setting, political parties do not need an "ideology," nor in fact even a "philosophy," but merely political strategies for practical application. ${ }^{86}$ This prescription for political parties should obviously preclude the existence of ideologically charged parties such as the CCP or the GMD in a future Chinese democracy. Tang completed his exhortation by adding that practical politics had to be concerned with concrete and particular issues, which was why politicians should refrain from relying on abstract principles and theories. ${ }^{87}$ Otherwise, there was a risk of falling victim to an ideologization of politics that might engender totalitarianism. Such a type of politics is characterized, according to Tang, by the ambition to realize truth claims "immediately" and within all social and cultural sectors.

By rejecting calls to a comprehensive realization of political doctrines, the modern Confucian project is most of all about retracing ideational foundations of democracy and freedom - and not about efforts to implement doctrines and prescriptions. ${ }^{88}$ Tang was therefore merely being consistent when stating that "our scholarship" should not be directly turned into a political force. ${ }^{89}$ The idea here is that democratic discussions among citizens about which traditions to follow and how to interpret the normative foundations of their collective life require a humanistic realm that is free from direct interference by political

\footnotetext{
84 Tang, Renwen jingshen zhi chongjian, p. 391; see also ibid., pp. 66-67.

85 Tang, Zhonghua renwen yu dangjin shijie bubian, Vol. 10, pp. 226-227. On Tang's notion of politics as a sector within the "domains of human culture," see also Tang, Renwen jingshen zhi chongjian, p. 389. "Culture" and "society" are used here as umbrella terms, that is, in a very broad sense.

86 Tang, Zhonghua renwen yu dangjin shijie bubian, Vol. 10, p. 226.

87 Ibid., p. 227.

88 Ibid., p. 236 .

89 Ibid., p. 227.
} 
ideologies and power politics. As a consequence, no particular humanistic tradition should obtain political protection above all others and this includes Confucianism. Tang's reluctance to provide a detailed, prescriptive depiction of Confucian humanism is therefore not due to a lack of practical concerns. On the contrary, the relative vagueness of Confucian humanism functions to prevent its abuse by political ideologies, and thus facilitates open deliberations about its contents and meanings among citizens in the first place. By raising the awareness for the need of such open deliberations, modern Confucianism is conducive to establishing a political culture that befits liberal democracy.

Unlike what one may generally expect from a Confucian philosopher, Tang did not support the idea that, in modernity, politics should be refueled with ethical values so as to fully reestablish the "representational value of the political."90 Instead of longing for a substantial reintegration of politics and ethics, Tang chose virtually the opposite direction by relieving politics from claims to a higher moral truth. From now on, the field of politics was to be seen as characterized by the quest for power of contesting wills and the institutional and procedural arrangements for mitigating these contests. Even though cultural, social, or ethical values are not completely dysfunctional within politics, let alone absent from politics altogether, the operational logic of politics itself is not determined by such value orientations.

With this approach of differentiation, Tang sought to address challenges to constitutional democracy as he perceived them in the 1950s and 196os, while at the same time rejecting the ideological lures of a concept of pure politics incorporating a higher morality, a scientific truth, or a historical necessity. He therefore deplored the fact that, on the Chinese Mainland after 1949, political rule had completely dominated the humanistic realm. In the "modern Qin Dynasty," as he called it, the CCP had elevated politics to the highest position in the whole sphere of culture in order to subdue the "humanistic world." The respective socialist theories of art and science should be discarded, according to Tang, because they submit the arts and sciences in total to political and economic standards. ${ }^{91}$

9o The term "representational value of the political" ("Repräsentationswert des Politischen") is borrowed from Bolz, who introduces it in his analysis of Walter Benjamin's critical remarks about the erosion of representational substance in democratic politics driven by the mounting dominance of mass media in politics: Bolz, "Charisma und Souveränität," p. 251.

91 Tang, Renwen jingshen zhi chongjian, pp. 65, 68, 388. This diagnosis of Tang has been refuted from a Marxist perspective by Zhang Xianghao, who criticized Tang's political 
With respect to contemporary (and future Chinese) liberal democracies, Tang supported, as we have seen, the idea of indirectly enhancing the representational value of democratic politics by reaffirming the importance of the humanistic realm. He was walking a fine line here. While rejecting the traditionalistic idea of resubmitting politics altogether to pre-modern ethical standards and values, he repudiated the idea of reducing politics to a purely functional sphere deplete of any normative contents. The middle position that Tang envisioned for politics is an elusive terrain which is difficult to demarcate conceptually, even though he set a perimeter around the two-fold dimension of dissociative and associative aspects of political action. On the one hand, he depicted the sphere of political action as characterized by a dissociative struggle for power which involves specific means, institutions, and procedures; on the other, he conceptualized a social sphere of humanistic culture and values which is said to function as a crucial normative input for fostering associative behavior in politics.

Such an expectation with respect to the political relevance of humanistic culture appears to be overly optimistic, while at the same time underestimating the increasing political impact of modern mass communication. Tang assumed, for example, the success of politicians in democratic elections to be the result of a broad acceptance of their value orientations by the constituency. ${ }^{92}$ In the same vein, he was convinced that the values represented by the constituency have a crucial impact on decisions about who is to be entrusted with political responsibility. ${ }^{93}$ To be fair, it should be mentioned again that Tang developed these views not as descriptions of extant democracies, but rather as to explore the normative potential of democracy. Indeed, when reflecting on the American democracy in his time, he not only observed an excess of instrumental values in politics, but also a dangerous tendency to turn democratic elections into a barter trade. Apparently both candidates and the constituency perceived each other as instrumental for the pursuit of their respective goals. Modern election campaigns are hence designed, Tang believed, to evoke a certain psychological condition in which the voters are easily incited. In a somber mood, he concluded that only those candidates get elected who are capable of inciting an emotional response in their constituency, whereas political personalities in the true sense of the word fail to be

thought for neglecting the "substance of classes" and disregarding the question of which class holds power to rule; see Zhang, Tang Junyi sixiang yanjiu, p. 161.

93 Tang, Zhonghua renwen yu dangjin shijie, Vol. 2, p. 132. 
elected. In the end, "human beings" are not elected, but the financial power behind the campaigns of the candidates. ${ }^{94}$

Even though these reflections on the downsides of modern democracy were in general agreement with pessimistic diagnoses of mass democracy in Europe and the United States, there are also some significant differences to be found. About two decades prior to Tang's critical view of American democracy, Walter Benjamin presented a profound critique of the modern parliament and its public. According to Benjamin, the technical innovations of radio and film were for the most part responsible for an essential change in the nature of political selection. Now, the new procedure of "presenting the politicians before the recording equipment" was gaining so much momentum that parliaments and theaters were likewise in a state of atrophy. Benjamin concluded that given this novel "selection before an apparatus," only "the champion, the star, and the dictator" would be able to succeed. ${ }^{95}$ Tang did not consider the distortion of democratic politics and the depletion of normative deliberation under the impact of mass communication with the same heightened attention as Benjamin. But even so, he also did not believe in the feasibility of replenishing modern democracy with rejuvenated forms of rule by virtue, nor did he advocate the idea of a Confucian democracy characterized by meritocratic standards of political selection.

As regards the modern politician, Tang's "humanistic" concept of the political suggests an ideal which is quite different from the one found in the thought of Max Weber, even though Tang, like Weber, expected politicians to resist the lure of an ethics of conviction. But the ideal politician described by Tang does not belong to the Weberian type of modern, professional politician who lives for and from his or her political activities. Tang rather envisioned politicians who reluctantly engage into politics and conscientiously acknowledge that they do not directly contribute to the realization of common values. ${ }^{96}$ Such political personalities should be persons of broad humanistic education who do not use their power to suppress others, but to "treasure culture." ${ }^{\text {97 }}$ They are thus "worthy persons" of humanistic background who volunteer to shoulder the burden of political engagement. Due to such a lack of political passion, ideal politicians would find it easier to stay impartial and free from partisanship

94 Ibid., pp. 137-138.

95 Benjamin, The Work of Art in the Age of Its Technological Reproducibility, and Other Writings on Media, p. 5o, Endnote 24 (for the German original, see Benjamin, Das Kunstwerk im Zeitalter seiner technischen Reproduzierbarkeit, pp. 27-28; Footnote 20).

96 Tang, Renwen jingshen zhi chongjian, p. 390.

97 Ibid., pp. 67, 394. 
when assuming higher office..$^{98}$ They would hence remain aloof from social and political pressure groups and resist the paralyzing pressure of bureaucratic mechanisms. Even though Tang referred here explicitly to an ideal, one may still wonder whether his political thought is not prone to an elitist elevation of personalities of humanistic breadth. In this regard, his portrayal of ideal politicians and his requirements for practitioners of self-cultivation are in conformity insofar as both depict outstanding individuals capable of bearing up under the failures of their efforts when facing the downsides of the modern world.

$98 \quad$ Ibid., p. 394. 